\title{
Tracing the occurrence of the Critically Endangered smalltooth sawfish Pristis pectinata at its southernmost distribution in the Southwest Atlantic Ocean
}

\author{
Juan Martín Cuevas ${ }^{1,2, *}$, Mirta García ${ }^{2,3}$, Natalia Hozbor ${ }^{4}$, Vicente V. Faria ${ }^{5}$, \\ Laura Paesch ${ }^{6}$
}

${ }^{1}$ Wildlife Conservation Society de Argentina, Amenabar 1595, C1426AKC, Ciudad Autónoma de Buenos Aires, Argentina

${ }^{2}$ División Zoología Vertebrados, Museo de la Plata, Universidad Nacional de la Plata, Paseo del Bosque s/n, 1900, La Plata, Argentina

${ }^{3}$ Consejo Nacional de Investigaciones Científicas y Técnicas (CONICET), Godoy Cruz 2290, C1425FQB,

Ciudad Autónoma de Buenos Aires, Argentina

${ }^{4}$ Instituto Nacional de Investigación y Desarrollo Pesquero (INIDEP), Paseo Victoria Ocampo No 1, Escollera Norte, B7602HSA, Mar del Plata, Argentina

${ }^{5}$ Departamento de Biologia, Centro de Ciências, Universidade Federal do Ceará - UFC, Campus do Pici, Bl. 906, Av. Mister Hull, s/n, 60440-900, Fortaleza, Brazil

${ }^{6}$ Dirección Nacional de Recursos Acuáticos (DINARA), Calle Constituyente $\mathbf{N}^{\circ} 1476,11.200$, Montevideo, Uruguay

\begin{abstract}
Sawfishes are the most globally threatened group of sharks, rays, and chimaeras. One of the 5 sawfish species is the Critically Endangered smalltooth sawfish Pristis pectinata. Although it is currently found in only a small portion of its historical range, this species was once distributed along tropical and subtropical coasts on both sides of the Atlantic Ocean. Its historical distribution included the Southwest Atlantic in Brazil and Argentina, with its presence in Uruguay assumed from its occurrence in neighboring countries. However, occurrence records in this region have only been compiled for Brazil. The aim of this study was to characterize the occurrence of P. pectinata in the Argentinean-Uruguayan Common Fishing Zone (AUCFZ). Quantitative sampling data revealed no sawfish specimens during 150 bottom trawl cruises and 8490 hauls (1905 in winter; 1647 in fall; 3141 in spring; 1797 in summer months) in the AUCFZ between 1981 and 2015. Nevertheless, qualitative data based on interviews $(\mathrm{N}=275$; researchers, fishing companies, fishermen, and recreational anglers) supports the occasional presence of sawfish in the AUCFZ. Five new oral reports were obtained and, although these records lack reference material, they have an associated capture year: 2 records from the 1950s, 1 record from the 1990s, and 2 records from the 2010s. Two of these records are the first for Uruguay and were reported by experienced fishermen. We conclude that the species was always a vagrant to the region, and suggest that the view of $P$. pectinata as extirpated from Uruguay and northern Argentina should be revisited.
\end{abstract}

KEY WORDS: Pristidae $\cdot$ Elasmobranchs $\cdot$ Bottom trawling $\cdot$ Southwest Atlantic $\cdot$ Oral reports

\section{INTRODUCTION}

Sawfishes (family Pristidae) are among the largest marine and euryhaline fishes. Collectively, the 5 extant sawfish species were formerly globally distributed in tropical and subtropical coastal, estuarine,

*Corresponding author: jcuevas@wcs.org and in some instances, freshwater habitats (Faria et al. 2013, Dulvy et al. 2016). However, with the local extinction and severe depletion of most populations, global sawfish distribution has been vastly reduced; sawfishes are extirpated from 20 countries, and 43 countries have at least one species classified as Possi-

() The authors 2019. Open Access under Creative Commons by Attribution Licence. Use, distribution and reproduction are unrestricted. Authors and original publication must be credited. 
bly Extinct (Dulvy et al. 2016). These population depletions have made sawfishes the most threatened group of chondrichthyans (Dulvy et al. 2014, Fernandez-Carvalho et al. 2014). According to the International Union for the Conservation of Nature's (IUCN) Red List of Threatened Species, 3 sawfish species (Pristis pristis, P. pectinata, and P. zijsron) are currently classified as Critically Endangered (Carlson et al. 2013, Kyne et al. 2013a, Simpfendorfer 2013). The remaining two (Anoxypristis cuspidata and P. clavata) are Endangered (D'Anastasi et al. 2013, Kyne et al. 2013b). All 5 species are also listed in Appendix I of the Convention on International Trade of Endangered Species (CITES) (Carlson et al. 2013). In addition, the smalltooth sawfish $P$. pectinata has been listed under the US Endangered Species Act since 2003 by the US National Marine Fisheries Service (NMFS 2003).

The historical distribution of $P$. pectinata includes tropical and subtropical coasts on both sides of the Atlantic Ocean (Faria et al. 2013). However, P. pectinata population reduction is inferred at $95 \%$ over a period of 3 generations (Carlson et al. 2013). In addition, this species has suffered an $81 \%$ geographical reduction of its original range (Dulvy et al. 2016). As a consequence, the distribution of $P$. pectinata is now patchy, and it is possible that only remote parts of the Caribbean Sea could host any viable populations outside US waters (NOAA 2013).

Even though this perception of large-scale depletion outside the USA is undisputed, regional and local information about the contemporary occurrence of $P$. pectinata is mostly scarce outside of Florida. For example, $P$. pectinata is considered no longer present in the eastern south American countries of Brazil, Uruguay, and Argentina (Charvet \& Faria 2014), yet Brazil is the only country in the region for which historical $P$. pectinata records have recently been reviewed. Historical records are distributed along the Brazilian coast (Faria \& Charvet-Almeida 2008), thus suggesting a once large range there. The last known record of $P$. pectinata for Brazil, however, refers to Thorson's (1974) report for saws traded in northern Brazil in the 1960s and 1970s (Faria \& CharvetAlmeida 2008, Charvet \& Faria 2014, Manir Feitosa et al. 2017). Unlike $P$. pectinata records in Brazil, information from the other eastern South American countries, Uruguay and Argentina, is limited.

$P$. pectinata has never been recorded in Uruguay (Charvet \& Faria 2014); its presence in the country (Nion et al. 2002, Meneses \& Paesch 2003) has only been inferred from Argentine records (Lahille 1906, 1921). These records refer to specimens 180 and
$205 \mathrm{~cm}$ in total length (TL), both from Mar del Plata (Lahille 1921). In the same area $\left(38^{\circ} 52^{\prime} \mathrm{S}, 56^{\circ} 16^{\prime} \mathrm{W}\right)$, 5 decades later in 1971, an unidentified sawfish (most likely $P$. pectinata) measuring 300-400 cm TL was encountered (Menni et al. 2010).

Besides the aforementioned records for Argentina, no effort has been directed towards investigating other potential sources of sawfish records for Argentina and Uruguay. Such records could clarify its occurrence in these countries. Given this lack of knowledge and the Critically Endangered status of $P$. pectinata, the aim of this study was to characterize the occurrence of this irregularly occurring species in the Argentinean-Uruguayan Common Fishing Zone (AUCFZ) using quantitative and qualitative data.

\section{MATERIALS AND METHODS}

\subsection{Study area}

The Southwest Atlantic Ocean (SWA) is a global hotspot of threatened chondrichthyans; $50 \%$ of endemic species in this region are threatened with extinction (Dulvy et al. 2014). At the same time, these areas of high chondrichthyan diversity in the SWA are associated with marine front areas of high biological activity (Lucifora et al. 2012). These areas, formed by the confluence of different water masses, have enormous biological productivity as a result of the input of nutrients (Acha et al. 2004). Our study area is located within the SWA and covers the AUCFZ (Fig. 1). It includes the outer region of the La Plata River and its adjacent inner continental shelf, the Argentine and Uruguayan coast (depth <50 m) and the outer continental shelf (50 to $420 \mathrm{~m}$ ) in the SWA $\left(34^{\circ} 30^{\prime}\right.$ to $39^{\circ} 30^{\prime} \mathrm{S}, 52^{\circ} 00^{\prime}$ to $\left.59^{\circ} 00^{\prime} \mathrm{W}\right)$, covering 35.848 square nautical miles $\left(\mathrm{nmi}^{2}\right)$. This area is the meeting point of 3 different water masses: freshwater flow from the La Plata River; the Brazil Current; and the Malvinas/Falkland Current. It is characterized by high spatio-temporal variability in hydrographic parameters and primary productivity (Acha et al. 2004).

\subsection{Data collection}

\subsubsection{Historical records and interviews}

First, an exhaustive literature review was carried out to search for old records in local fish catalogues, published journals, theses, and technical reports as 
well as local newspapers and fishing magazines. Then, the ichthyological collections of museums (Table 1), research institutions, and universities in Argentina and Uruguay were examined in 2015 for historical records of Pristis pectinata, and each individual sawfish was identified according to Lahille (1906), Bigelow \& Schroeder (1953), and Faria et al. (2013).

Survey interviews $(\mathrm{N}=275)$ were then conducted with ichthyologists (Argentina, $\mathrm{n}=42$; Uruguay, $\mathrm{n}=9$ ), recreational anglers (Argentina, $\mathrm{n}=$ 138; Uruguay, $\mathrm{n}=5$ ), artisanal fishermen (Argentina, $\mathrm{n}=28$; Uruguay, $\mathrm{n}=$ 51), and the 2 oldest and largest frozen seafood companies in the AUCFZ. These interviews were conducted from September 2015 to December 2016. A simple questionnaire was used for interviews (see Text S1 in the Supplement at www.int-res.com/ articles/suppl/n038p001_supp.pdf). Each interview was conducted in person, by telephone, or through social

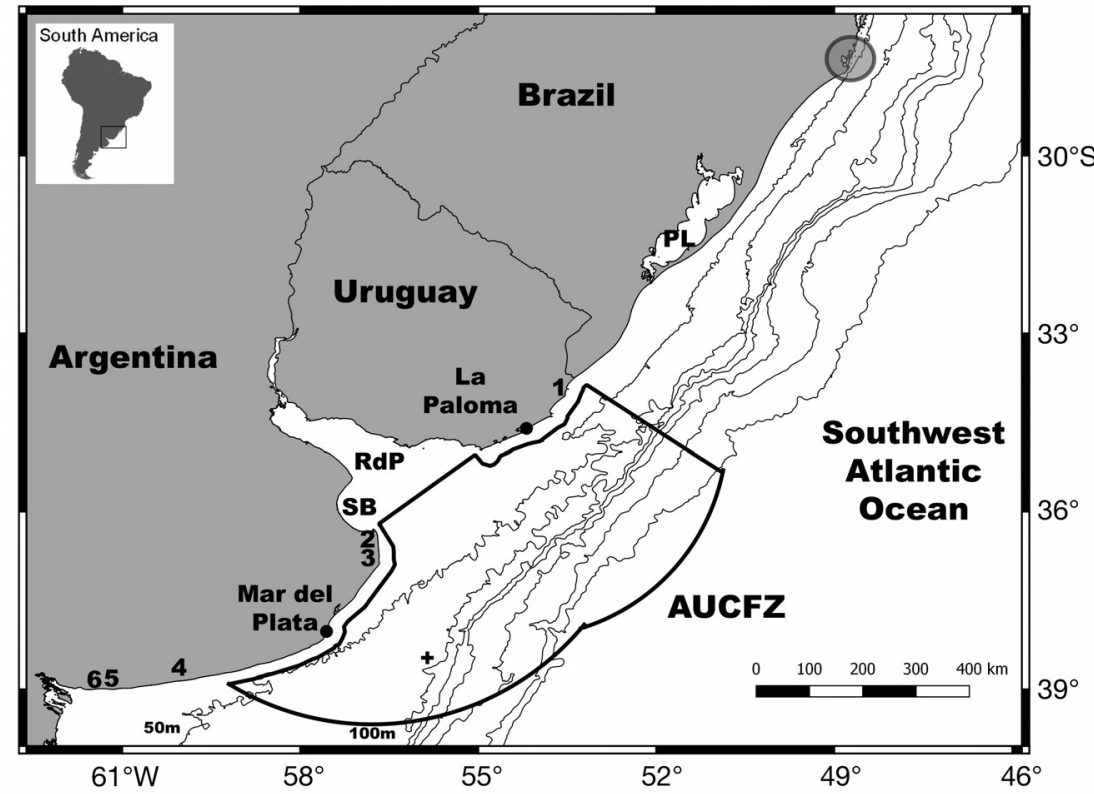

Fig. 1. Study area. PL: Patos Lagoon; RdP: La Plata River; SB: Samborombón Bay; AUCFZ: Argentine-Uruguayan Common Fishing Zone. (+) indicates the location of the last confirmed sawfish record in the study area in 1971, probably Pristis pectinata. Grey circle: southern limit of the red mangrove Rhizophora mangle in the Southwest Atlantic. Artisanal fishermen communities 1: Punta del Diablo; 2: San Clemente del Tuyú; 3: Mar de Ajó; 4: Claromecó; 5: Monte Hermoso; 6: Pehuencó media (Facebook). In Uruguay, inter-

views were conducted with artisanal fishermen at La Paloma. In Argentina, interviews with recreational anglers and artisanal fishermen were focused on the Buenos Aires coast to cover areas close to the AUCFZ (communities 2-6 in Fig. 1). Interviews for the 2 frozen seafood companies were conducted at their headquarters in Mar del Plata (Fig. 1). Currently, 14 frozen seafood companies operate in Uruguay and are responsible for fisheries landing records for the ports of Montevideo and La Paloma.

Finally, all fishery landing records belonging to the Dirección Nacional de Recursos Acuáticos (DINARA; The National Directory for Aquatic Resources) from 1977 to 2017 were checked for any sawfish landings. Additional consultations were conducted with regional experts $(n=54)$, including authors of published chondrichthyan species catalogues for Argentina and Uruguay that include $P$. pectinata.

\subsubsection{Research surveys}

In Argentina, data collected from 73 bottom trawl research cruises in the AUCFZ between 1981 and 2015 by research vessels (RV) operated by Argentina's Instituto Nacional de Investigación y Desarrollo
Pesquero (INIDEP; National Institute for Fisheries Research and Development) were analyzed for records of sawfishes. Of these cruises, 33 were conducted in coastal waters (depths $<50 \mathrm{~m}$ ), and the remaining 40 were in the outer continental shelf (depths between 50 and $250 \mathrm{~m}$ ). Each coastal trawl station (haul) consisted of a 15 min tow during daylight at a speed of 3-4 knots. The outer stations used 30 min tows at the same speed. During both hauls, a high-opening 'Engel' type bottom trawl was used with a stretched mesh of $100 \mathrm{~mm}$, cod-end, and horizontal mouth opening of 19-22 m.

In Uruguay, data from 79 bottom trawl research cruises collected in the AUCFZ between 1984 and 2015 were examined and analyzed. Fifteen of these research cruises were conducted by the RV 'Cruz del Sur' (1984-1989), while the remaining 64 were conducted by the RV 'Aldebarán' (1991-2015) operated by DINARA. Of these 79 cruises, 32 were coastal and 47 were conducted on the outer continental shelf. Hauls were selected using a stratified random sample design, and each trawl consisted of a 30 min tow during daylight at a speed of 3-4 knots. A high-opening 'Engel' type bottom trawl with a stretched mesh of $80-100 \mathrm{~mm}$, cod-end, and 55-60 m horizontal mouth was used. 
Table 1. Rostral records of sawfishes from ichthyological collections in Argentina and Uruguay. MLP: Museo de la Plata. (-) No data

\begin{tabular}{|c|c|c|c|c|c|c|c|c|}
\hline Code & $\begin{array}{l}\text { No. } \\
\text { rostral } \\
\text { teeth } \\
\text { side }^{-1}\end{array}$ & $\begin{array}{l}\text { Total } \\
\text { rostral } \\
\text { length } \\
(\mathrm{cm})\end{array}$ & Species & $\begin{array}{c}\text { Original } \\
\text { ocean } \\
\text { basin }\end{array}$ & $\begin{array}{c}\text { Date } \\
\text { (dd/mm/yyyy) }\end{array}$ & $\begin{array}{l}\text { Sample } \\
\text { source }\end{array}$ & Name & Country \\
\hline MLP 10899 & 31 & 98 & P. zijsron & - & - & Museum & Museo de La Plata & Argentina \\
\hline MLP 10900 & 27 & 68 & A. cuspidata & Indian Ocean & - & & & \\
\hline MLP 10912 & 25 & 46 & A. cuspidata & - & - & & & \\
\hline MLP 10913 & 26 & 69 & A. cuspidata & - & - & & & \\
\hline MLP 10914 & 23 & 72 & P. pectinata & - & - & & & \\
\hline General catalogue & 27 & 124 & Pristis zijsron & $\begin{array}{l}\text { Indian } \\
\text { Ocean }\end{array}$ & 02/03/1906 & Museum & $\begin{array}{l}\text { Museo Argentino de } \\
\text { Historia Natural } \\
\text { 'Bernardino Rivadavia' } \\
\text { (MACN) }\end{array}$ & Argentina \\
\hline General catalogue & 24 & 138 & P. zijsron & & 02/03/1906 & & & \\
\hline General catalogue & 16 & 88 & P. pristis & & 02/03/1906 & & & \\
\hline - & - & - & - & - & - & Museum & $\begin{array}{l}\text { Museo de Historia } \\
\text { Natural y Antropología } \\
\text { de Montevideo }\end{array}$ & Uruguay \\
\hline - & 22 & 108 & P. zijsron & - & - & University & $\begin{array}{l}\text { Cátedras de Zoología III } \\
\text { Vertebrados. Facultad } \\
\text { de Ciencias Naturales } \\
\text { y Museo (FCNyM) }\end{array}$ & Argentina \\
\hline - & 27 & 73 & A. cuspidata & - & - & University & $\begin{array}{l}\text { Cátedra de Ictiología. } \\
\text { Facultad de Ciencias Natu } \\
\text { rales y Museo (FCNyM) }\end{array}$ & Argentina \\
\hline - & - & - & - & - & - & University & $\begin{array}{l}\text { Facultad de Ciencias } \\
\text { de la Univer sidad } \\
\text { de la República }\end{array}$ & Uruguay \\
\hline - & - & - & - & - & - & $\begin{array}{l}\text { Research } \\
\text { institute }\end{array}$ & $\begin{array}{l}\text { Instituto Nacional de } \\
\text { Investigación y Desarrollo } \\
\text { Pesquero (INIDEP) }\end{array}$ & Argentina \\
\hline - & - & - & - & - & - & $\begin{array}{l}\text { Frozen } \\
\text { seafood } \\
\text { company }\end{array}$ & Moscuzza & Argentina \\
\hline- & - & - & - & - & - & $\begin{array}{l}\text { Frozen } \\
\text { seafood } \\
\text { company }\end{array}$ & Frigorífico del Sudeste & Argentina \\
\hline
\end{tabular}

We assume here that the trawling speed and duration (15 and $30 \mathrm{~min}$ ) used during the hauls carried out in each country could potentially capture sawfishes. This is based on the fact that these trawls captured other benthic batoids with similar size ranges as $P$. pectinata. On the other hand, we considered that the likelihood of these surveys capturing sawfish was low. This is because sawfish global declines were already in place by the time these surveys started in the 1980s.

\section{RESULTS}

\subsection{Interviews}

Interviews conducted with fishermen did reveal new evidence of the presence of sawfish in the region.
However, these new instances lacked associated reference material such as photos or dried rostra and are therefore currently considered anecdotal.

Interviews with Uruguayan artisanal fishermen resulted in 3 oral reports of Pristis pectinata (Table 2); their fishing experience ranged from 25 to $45 \mathrm{yr}$ $($ mean $\pm \mathrm{SD}=25.6 \pm 3.1 \mathrm{yr}$ ). The 3 records were as follows: (1) 1 specimen of about $150 \mathrm{~cm}$ TL landed at La Paloma port in 1954; (2) 1 specimen (unknown TL) caught by commercial fishing vessels near Pozo del Fango between 1997 and 1998; and (3) 1 specimen ( $80 \mathrm{~cm}$ TL) caught by commercial fishing vessels in the Papamoscas fishing zone between Uruguay and Argentina in 2010. Interviews with Argentinian artisanal fishermen yielded no records of $P$. pectinata; these fishermen's fishing experience ranged from 7 to $73 \mathrm{yr}(23.8 \pm 15.7 \mathrm{yr})$. 
Table 2. Interviews with fishermen with sightings of sawfishes in the Argentinean-Uruguayan Common Fishing Zone. Oral reports lacked reference material (i.e. no rostra, photo or video). (-) No data available

\begin{tabular}{|c|c|c|c|c|c|c|c|c|}
\hline Type & $\begin{array}{c}\text { - Fisherman } \\
\text { Age } \\
\text { (yr) }\end{array}$ & $\begin{array}{c}\text { Experience } \\
(\mathrm{yr})\end{array}$ & $\begin{array}{c}\text { Date of } \\
\text { sighting }\end{array}$ & $\mathrm{n}$ & $\begin{array}{l}\text { Estimated } \\
\text { total length } \\
(\mathrm{cm})\end{array}$ & Locality & Coordinates & Comments \\
\hline \multirow[t]{2}{*}{ Artisanal } & 65 & 45 & 1954 & 1 & 150 & La Paloma, Uruguay & $\begin{array}{l}34^{\circ} 39^{\prime} 31^{\prime \prime} \mathrm{S} \\
54^{\circ} 8^{\prime} 50^{\prime \prime} \mathrm{W}\end{array}$ & $\begin{array}{l}\text { Captured, landed at } \\
\text { La Paloma Port }\end{array}$ \\
\hline & & & 1997-1998 & 1 & - & Pozo del Fango, Uruguay & $34^{\circ} 47^{\prime} \mathrm{S}, 53^{\circ} 45^{\prime} \mathrm{W}$ & Captured, fate unknown \\
\hline Angler & 74 & 17 & 1958 & 1 & $<100$ & $\begin{array}{l}\text { Punta Iglesias, Mar del } \\
\text { Plata, Argentina }\end{array}$ & $\begin{array}{l}37^{\circ} 59^{\prime} 59.74^{\prime \prime} \mathrm{S} \\
57^{\circ} 32^{\prime} 18.30^{\prime \prime} \mathrm{W}\end{array}$ & Captured, fate unknown \\
\hline Artisanal & 50 & 35 & 2010 & 1 & $70-80$ & $\begin{array}{l}\text { Papamoscas, } 80 \text { nmi south } \\
\text { of La Paloma, Uruguay }\end{array}$ & - & Captured, fate unknown \\
\hline Angler & 24 & 15 & 2012 & 1 & - & $\begin{array}{l}\text { Mar Chiquita Lagoon, } \\
2 \text { km east, Argentina }\end{array}$ & - & Captured, released alive \\
\hline
\end{tabular}

Table 3. Confirmed records of sawfishes in the Argentinean-Uruguayan Common Fishing Zone

\begin{tabular}{|c|c|c|c|c|c|c|c|}
\hline Date & Season & Species & $\mathrm{n}$ & Size $(\mathrm{cm})$ & Site & Country & Source \\
\hline $1906^{\mathrm{a}}$ & $?$ & Pristis pectinata & $?$ & ? & Mar del Plata & Argentina & Lahille (1906) \\
\hline $1921^{\mathrm{a}}$ & $?$ & Pristis pectinata & 2 & 180,205 & Mar del Plata & Argentina & Lahille (1921) \\
\hline 1971 & Summer & Pristis sp. ${ }^{\mathrm{b}}$ & 1 & $300-400$ & Station No. 346 : $38^{\circ} 52^{\prime} \mathrm{S}, 56^{\circ} 16^{\prime} \mathrm{W}$ & Argentina & Menni et al. (2010) \\
\hline
\end{tabular}

The presence of sawfish in the area was also reported by anglers, who described reported 2 sawfish encounters in Argentina: (1) 1 specimen of less than $100 \mathrm{~cm}$ TL from the Mar del Plata port in 1958 and (2) 1 specimen (unknown TL) $\sim 2 \mathrm{~km}$ east of the mouth of Mar Chiquita Lagoon in 2012. Angler fishing experience ranged from 2 to $57 \mathrm{yr}$ in Argentina (23.4 \pm $12.6 \mathrm{yr})$ and from 13 to $30 \mathrm{yr}$ in Uruguay $(16.4 \pm 7.6 \mathrm{yr})$ (Table 2).

The remaining sources of information did not produce any new sawfish records. These were: (1) interviews with Uruguayan and Argentinian ichthyologists - their research experience ranged from 15 to $50 \mathrm{yr}$ in both countries (Argentina, $24.1 \pm 12.3 \mathrm{yr}$; Uruguay, $27.2 \pm 11.5 \mathrm{yr}$ ); (2) historical records from seafood companies - the 2 oldest frozen seafood companies in Argentina: Moscuzza (96 yr) and Frigorífico del Sud Este (73 yr); and (3) Uruguayan fishery statistics - based on all declared captures from Uruguay landed in the ports of Montevideo and La Paloma since 1977.

\subsection{Historical records}

No additional sightings of $P$. pectinata were recorded in the region after Lahille $(1906,1921)$ for
Argentina (Table 3). This species was only listed nominally in several marine fish lists for Argentina (Pozzi \& Bordalé 1935, Ringuelet \& Arámburu 1961, Menni et al. 1984, Menni \& Stehmann 2000, Chebez \& Athor 2009, 2013, Figueroa 2011) and for Uruguay (Nion et al. 2002, Meneses \& Paesch 2003). But at the same time, other authors did not include $P$. pectinata for either Argentina or Uruguay (De Buen 1950, Abella et al. 1979, Cousseau 1985, Boschi 1988, Carlson et al. 2013, CMS 2014).

No sawfish specimens with locality data associated with Argentina or Uruguay were found in the regional ichthyological collections visited. Therefore, the only $P$. pectinata dried rostrum found (10914; Table 1) without a locality or collection date cannot be assumed to have been removed from a specimen collected in the region. Sawfish rostra deposited in ichthyological collections of Argentina were mostly acquired from European private collectors in the early 1900 s.

\subsection{Research surveys}

No sawfish specimens were recorded during research surveys. Data from 152 bottom trawl cruises and 8490 hauls (winter: 1905; autumn: 1647; spring: 
3274; summer: 1797; Tables 4 \& S1-S4) with a total covered area of $185.78 \mathrm{nmi}^{2}$ yielded no sawfish records in Argentina or Uruguay between 1981 and 2015 (Fig. 2).

\section{DISCUSSION}

The present study suggests that the view of sawfishes as extirpated from Uruguayan and Argentinean waters should be revisited. This is based on anecdotal evidence of the relatively recent presence of sawfish in the AUCFZ.

Pristis pectinata is currently still considered possibly extinct along the coast of 15 countries in the east Atlantic and 16 countries in the west Atlantic (Carlson et al. 2013). The absence of any sawfish records in ichthyological collections, bibliographies, fisheries records, and the last $35 \mathrm{yr}$ of research cruise data from the AUCFZ may match an extinction scenario. However, interviews conducted in the present study with fishermen have now challenged this regionally extinct status.

The new reports obtained from fishermen interviews rely on the testimony of 2 professional fishermen and 2 recreational fishermen. Due to the absence of any specimens, photos, or other documented evidence, these records can not be regarded as conclusive evidence of the present-day occurrence of $P$. pectinata in the AUCFZ. Nevertheless, it is valuable that these fishermen knew what a sawfish looks like. In addition, no other similar species (i.e. sawsharks or swordfish) occur in the study area. Therefore, a misidentification of a sawfish in the region is highly unlikely.

At least 2 of the newly obtained oral records for relatively recent occurrences of sawfish in the AUCFZ appear to be reliable. These were obtained from 2 experienced fishermen from Uruguay. Colleagues from DINARA conducted the interviews (DINARA is an institution that has historically collaborated closely with local fishermen). In the 1997-1998 Pozo del Fango case, the fisherman was fishing and witnessed the capture of the specimen. In the 2010 record, the fisherman was fishing in the sea between the Uruguayan-Argentinean border. The specimen was killed and brought on board, but it was lost (either thrown away or stolen). The experience of the fishermen and the detailed accounts provided for the fishing capture event, such as site locality, bottom and vegetation type, and gillnet mesh size of $18 \mathrm{~cm}$ (Table 2), make this report credible.
It is likely that $P$. pectinata has always been a vagrant in the region. Vagrancy is defined as those individuals that are/were 'recorded once or sporadically, but $[\ldots]$ known not to be native to the area' (IUCN 2013, p. 64). In this sense, the largetooth $P$. pristis and smalltooth sawfishes have been recorded as vagrant in the Mediterranean Sea (Ferretti 2014) and in southwest Australia (Last \& Stevens 2009). Since the first sighting of $P$. pectinata in 1906 in Argentina, only a few historical confirmed and sporadic records have been documented in the area (Tables 3 \& 4). In addition, fishermen are mostly unaware of the existence and/or decline of this species in the region.

Table 4. Research cruise information by season conducted in Argentina and Uruguay without records of Pristis pectinata in the study area between 1981 and 2015. S: Spring; Su: Summer; A: Autumn; W: Winter. Sources: Dirección Nacional de Recursos Acuáticos (DINARA) (Uruguay) and Instituto Nacional de Investigación y Desarrollo Pesquero (INIDEP) (Argentina)

\begin{tabular}{|c|c|c|c|}
\hline Year & Season & Country & $\begin{array}{l}\text { Sampling } \\
\text { effort (no. } \\
\text { of hauls) }\end{array}$ \\
\hline 1981 & $\mathrm{~S}$ & Argentina and Uruguay & 47 \\
\hline 1983 & $\mathrm{Su}, \mathrm{A}$ & Argentina and Uruguay & 101 \\
\hline 1984 & $\mathrm{~S}, \mathrm{Su}, \mathrm{A}, \mathrm{W}$ & Argentina and Uruguay & 356 \\
\hline 1985 & $\mathrm{~S}, \mathrm{Su}, \mathrm{A}, \mathrm{W}$ & Argentina and Uruguay & 320 \\
\hline 1986 & $\mathrm{Su}$ & Argentina and Uruguay & 80 \\
\hline 1987 & $\mathrm{~S}, \mathrm{~W}$ & Argentina and Uruguay & 139 \\
\hline 1988 & $\mathrm{Su}, \mathrm{A}, \mathrm{W}$ & Argentina and Uruguay & 304 \\
\hline 1989 & W & Argentina and Uruguay & 80 \\
\hline 1991 & $\mathrm{Su}, \mathrm{A}, \mathrm{W}$ & Argentina and Uruguay & 247 \\
\hline 1992 & $\mathrm{~S}$ & Argentina and Uruguay & 95 \\
\hline 1993 & $\mathrm{~S}$ & Argentina and Uruguay & 258 \\
\hline 1994 & $\mathrm{Su}, \mathrm{A}, \mathrm{W}$ & Argentina and Uruguay & 523 \\
\hline 1995 & $\mathrm{~S}, \mathrm{Su}, \mathrm{A}, \mathrm{W}$ & Argentina and Uruguay & 567 \\
\hline 1996 & $\mathrm{~S}, \mathrm{Su}$ & Argentina and Uruguay & 425 \\
\hline 1997 & $\mathrm{~S}, \mathrm{Su}$ & Argentina and Uruguay & 326 \\
\hline 1998 & $\mathrm{~A}, \mathrm{Su}$ & Argentina and Uruguay & 359 \\
\hline 1999 & A & Argentina and Uruguay & 407 \\
\hline 2000 & $\mathrm{~A}, \mathrm{~S}$ & Argentina and Uruguay & 307 \\
\hline 2001 & $\mathrm{~S}, \mathrm{Su}, \mathrm{A}$ & Argentina and Uruguay & 406 \\
\hline 2002 & $\mathrm{~S}, \mathrm{~A}$ & Argentina and Uruguay & 144 \\
\hline 2003 & $\mathrm{~S}$ & Argentina and Uruguay & 259 \\
\hline 2004 & $\mathrm{~S}, \mathrm{~W}$ & Argentina & 154 \\
\hline 2005 & $\mathrm{~S}, \mathrm{~W}$ & Argentina and Uruguay & 351 \\
\hline 2006 & $\mathrm{Su}, \mathrm{A}, \mathrm{W}$ & Argentina and Uruguay & 460 \\
\hline 2007 & $\mathrm{~S}, \mathrm{Su}, \mathrm{A}$ & Argentina and Uruguay & 344 \\
\hline 2008 & $\mathrm{~S}, \mathrm{~A}$ & Argentina and Uruguay & 304 \\
\hline 2009 & $\mathrm{~S}, \mathrm{Su}, \mathrm{A}$ & Argentina and Uruguay & 209 \\
\hline 2010 & $\mathrm{Su}, \mathrm{A}$ & Argentina and Uruguay & 136 \\
\hline 2011 & $\mathrm{~S}, \mathrm{~A}, \mathrm{~W}$ & Argentina and Uruguay & 399 \\
\hline 2012 & $\mathrm{~S}, \mathrm{~W}$ & Argentina and Uruguay & 228 \\
\hline 2013 & $\mathrm{~S}, \mathrm{~W}$ & Argentina and Uruguay & 155 \\
\hline 2015 & $\mathrm{~S}$ & Uruguay & 133 \\
\hline
\end{tabular}



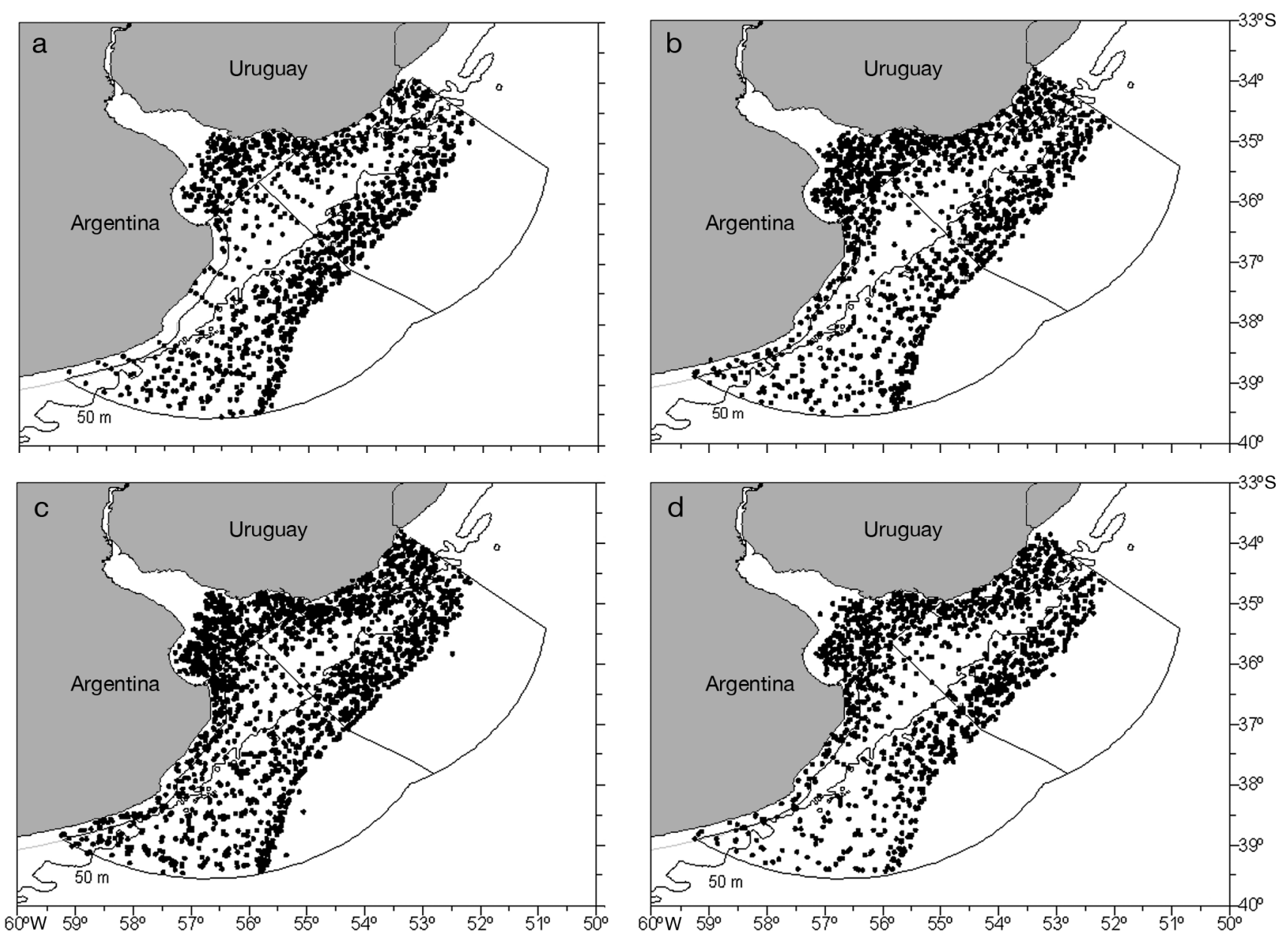

Fig. 2. Spatial distribution of the 8490 hauls from 152 research cruises by season conducted by Argentina and Uruguay in the study area between 1981 and 2015 during (a) autumn, (b) winter, (c) spring, and (d) summer

Overall, this suggests that a population was never established in Argentina and Uruguay. Thus, old records could refer to vagrant individuals from northern habitats (possibly the red mangroves from southern Brazil; Fig. 1), juveniles searching for new suitable estuarine habitats, or adults following prey as other demersal elasmobranchs do during the summer southward arrival of the Brazilian current into the AUCFZ (several elasmobranch species in the region display this seasonal behavior; Vooren 1997).

The fact that this species has not been recorded in Brazil for so long weakens a hypothesis of presentday migrants coming from Brazil. Nevertheless, the northwestern Atlantic population of $P$. pectinata in Florida and the Bahamas has been a successful example of sawfish conservation and recovery (Wiley \& Simpfendorfer 2010, Guttridge et al. 2015). Therefore, it is possible that this effort will gradually result in the presence of sawfish in areas where they have long been gone. This may help to enable the return of $P$. pectinata to the eastern coast of South America.

In conclusion, $P$. pectinata was always a vagrant to the region, and we suggest that the view of this species as extirpated from Uruguay and northern Argentina should be revisited. The present study is the first to focus on reviewing the occurrence of sawfishes within their distribution in the SWA. Despite the limitations of the evidence obtained, these records may serve as a call for further research in the region, leading towards collection of more rigorous evidence. For instance, one potentially useful technique is environmental DNA (eDNA). This technique investigates the presence of a species using samples collected in the environment. It has already been successfully applied to sawfishes (Simpfendorfer et al. 2016), as well as other elasmobranches (Boussarie et al. 2018). 
Acknowledgements. We thank A. Massa, R. Menni, G. Chiaramonte, C. Cuevas, A. Cuevas, C. Silva, M. Marchi, R. Ubieta, and R. Grassano for their help with the historical record acquisitions from Argentina. The 'Conservar Tiburones en Argentina' project provided the main 2.0 social media support for interviews. We are also grateful to $\mathrm{H}$. Nion for his valuable help with the historical record analysis from Uruguay and to G. Fabiano and O. Santana for interviewing old fishermen in Uruguay. Finally, authors thank anonymous reviewers for extensive comments and recommendations as well as A. Brautigam, N. Dulvy, C. Anderson and A. Padilla for suggestions on earlier versions of the manuscript. The authors have no conflict of interest to declare.

\section{LITERATURE CITED}

Abella A, Arena H, Ríos C (1979) Peces bentónicos del Río de la Plata y de la Zona Común De Pesca ArgentinoUruguaya. In: Memorias del seminario sobre ecología bentónica y sedimentación de la plataforma continental del Atlántico Sur. UNESCO ROSTLAC, Montevideo, p 291-323

Acha EM, Mianzan HW, Guerrero RA, Favero M, Bava J (2004) Marine fronts at the continental shelves of austral South America: physical and ecological processes. J Mar Syst 44:83-105

Bigelow HB, Schroeder WC (1953) Fishes of the Gulf of Maine. Fish Bull 53:1-577

Boschi EE (1988) El ecosistema estuarial del Río de la Plata (Argentina y Uruguay). Anal Inst Cien Mar Limnol UNAM 15:159-182. http://biblioweb.tic.unam.mx/cienciasdelmar/ instituto/1988-2/articulo313.html (accessed 2 Aug 2016)

Boussarie G, Bakker J, Wangensteen O, Mariani S and others (2018) Environmental DNA illuminates the dark diversity of sharks. Sci Adv 4:eaap9661

Carlson J, Wiley T, Smith K (2013) Pristis pectinata (smalltooth sawfish). The IUCN Red List of Threatened Species 2013:e.T18175A43398238. www.iucnredlist.org/details/ $18175 / 0$

Charvet P, Faria V (2014) Geographical distribution and status: Southwest Atlantic Ocean. In: Harrison LR, Dulvy NK (eds) Sawfish: a global strategy for conservation. IUCN Species Survival Commission's Shark Specialist Group, Vancouver, p 48-49

Chebez JC, Athor J (2009) Peces marinos amenazados de la Argentina. In: Chebez JC (ed) Los que se van. Fauna Argentina amenazada. Editorial Albatros, Buenos Aires, p 32-54

Chebez JC, Athor J (2013) Peces marinos amenazados de la Argentina. In: Chebez JC (ed) Otros que se van. Fauna Argentina amenazada. Editorial Albatros, Buenos Aires, p 55-65

CMS (Conservation of Migratory Species) (2014) Propuesta para incluir en los apéndices de la convención sobre la conservación de las especies migratorias de animales silvestres (CMS). Convention on the Conservation of Migratory Species of Wild Animals. UNEP/CMS/ScC18/ Doc.7.2.8, Propuesta I/8 y II/9

Cousseau MB (1985) Los peces del Río de la Plata y su frente marítimo. In: Yáñez-Arancibia A (ed) Fish community ecology in estuaries and coastal lagoons. Towards an ecosystem integration. UNAM Press México, México City, p 515-534

D'Anastasi B, Simpfendorfer C, van Herwerden L (2013)
Anoxypristis cuspidata (narrow sawfish). The IUCN Red List of Threatened Species 2013:e.T39389A18620409 www.iucnredlist.org/details/39389/0

* De Buen F (1950) El Mar de Solís y su fauna de peces (2da. Parte) S.O.Y.P. Public Cient Serv Oceanog y Pesca 2:1-144. http://www.nativefishlab.net/library/textpdf/ 12744.pdf (accessed 10 May 2016)

* Dulvy NK, Fowler SL, Musick JA, Cavanagh RD and others (2014) Extinction risk and conservation of the world's sharks and rays. eLife 3:e00590

*Dulvy NK, Davidson LNK, Kyne PM, Simpfendorfer CA, Harrison LR, Carlson JK, Fordham SV (2016) Ghosts of the coast: global extinction risk and conservation of sawfishes. Aquat Conserv 26:134-153

Faria VV, Charvet-Almeida P (2008) Pristis pectinata. In: Machado ABM, Drummond GM, Paglia AP (eds) Livro Vermelho da fauna Brasileira ameaçada de extinção (Série Biodiversidade). Fund Biodiversitas, Belo Horizonte, p 31-33

Faria VV, McDavitt MT, Charvet P, Wiley TR, Simpfendorfer CA, Naylor GJP (2013) Species delineation and global population structure of Critically Endangered sawfishes (Pristidae). Zool J Linn Soc 167:136-164

Fernandez-Carvalho J, Imhoff J, Faria V, Carlson J, Burgess G (2014) Status and the potential for extinction of the largetooth sawfish Pristis pristis in the Atlantic Ocean. Aquat Conserv 24:478-497

Ferretti F (2014) Geographical distribution and status: Mediterranean Sea. In: Harrison LH, Dulvy NK (eds) Sawfish: a global strategy for conservation. IUCN Species Survival Commission's Shark Specialist Group, Vancouver, p 50-51

Figueroa DE (2011) Clave ilustrada de agnatos y peces cartilaginosos de Argentina y Uruguay. In: Wöhler OC, Cedrola P, Cousseau MB (eds) Contribuciones sobre biología, pesca y comercialización de tiburones en la Argentina. Aportes para la colaboración del Plan de Acción Nacional. Consejo Federal Pesquero, Buenos Aires, p 25-74

Guttridge T, Gulak S, Franks B, Carlson J and others (2015) Occurrence and habitat use of the critically endangered smalltooth sawfish Pristis pectinata in the Bahamas. J Fish Biol 87:1322-1341

*IUCN (2013) Documentation standards and consistency checks for IUCN Red List assessments and species accounts, version 2. Adopted by the IUCN Red List Committee and IUCN SSC Steering Committee. https:// www.iucnredlist.org/resources/supporting-informationguidelines

Kyne PM, Carlson J, Smith K (2013a) Pristis pristis (largetooth sawfish). The IUCN Red List of Threatened Species 2013:e.T18584848A18620395 www.iucnredlist.org/details/ 18584848/0

Kyne PM, Rigby C, Simpfendorfer C (2013b) Pristis clavata (dwarf sawfish). The IUCN Red List of Threatened Species 2013:e.T39390A18620389 www.iucnredlist.org/ details/39390/0

Lahille F (1906) La pesca en la República Argentina. An Minist Agric 3:1-212

Lahille F (1921) Enumeración de los peces cartilaginosos encontrados en las aguas Argentinas. Physis 5:63-64

Last P, Stevens J (2009) Sharks and rays of Australia. CSIRO, Sydney

* Lucifora LO, García BV, Menni RC, Worm B (2012) Spatial patterns in the diversity of sharks, rays, and chimaeras 
(Chondrichthyes) in the Southwest Atlantic. Biodivers Conserv 21:407-419

Manir Feitosa L, Barbosa Martins AP, Silva Nunes JL (2017) Sawfish (Pristidae) records along the Eastern Amazon coast. Endang Species Res 34:229-234

Meneses P, Paesch L (2003) Guía de campo para la identificación de peces cartilaginosos del Río de la Plata y su frente oceánico. Frente Mar 19:145-193

Menni RC, Stehmann MFW (2000) Distribution, environment and biology of batoid fishes off Argentina, Uruguay and Brazil: a review. Rev Mus Argent Cienc Nat 2:69-109

Menni RC, Ringuelet R, Arámburu RH (1984) Peces marinos de la Argentina y Uruguay. Reseña histórica, clave de familias, géneros y especies. Catálogo crítico, Hemisferio Sur, Buenos Aires

Menni RC, Jaureguizar A, Stehmann M, Lucifora L (2010) Marine biodiversity at the community level: zoogeography of sharks, skates, rays and chimaeras in the southwestern Atlantic. Biodivers Conserv 19:775-796

Nion H, Ríos C, Meneses P (2002) Peces del Uruguay. Lista sistemática y nombres comunes. DINARA-INFOPESCA, Montevideo, p 1-104

NMFS (National Marine Fisheries Service) (2003) Endangered and threatened species; final endangered status for a distinct population segment of smalltooth sawfish (Pristis pectinata) in the United States. Fed Regist 68: 15674-15680

NOAA (National Oceanic and Atmospheric Administration)

Editorial responsibility: Dean Grubbs (Guest Editor), St. Teresa, Florida, USA
(2013) Endangered and threatened wildlife and plants; 12-month finding and proposed endangered listing of five species of sawfish under the Endangered Species Act. Fed Regist 78:48134

Pozzi A, Bordalé LF (1935) Cuadro sistemático de los peces marinos de la Argentina. An Soc Cient Argent 120: 145-189

Ringuelet RA, Arámburu RH (1961) Peces marinos de la República Argentina. Claves para el reconocimiento de familias y géneros. Catálogo crítico abreviado. Agro, La Plata

Simpfendorfer C (2013) Pristis zijsron (green sawfish). The IUCN Red List of Threatened Species 2013:e.T39393 A18620401 www.iucnredlist.org/details/39393/0

Simpfendorfer CA, Kyne PM, Noble TH, Goldsbury J and others (2016) Environmental DNA detects Critically Endangered largetooth sawfish in the wild. Endang Species Res 30:109-116

Thorson T (1974) Occurrence of sawfish, Pristis perotteti, in the Amazon River, with notes on $P$. pectinatus. Copeia 1974:560-564

Vooren CM (1997) Demersal elasmobranchs. In: Seeliger U, Odebrecht C, Castello JP (eds) Subtropical convergence environments: the coast and sea in the southwestern Atlantic. Springer, Berlin, p 141-146

*Wiley TR, Simpfendorfer CA (2010) Using public encounter data to direct recovery efforts for the endangered smalltooth sawfish Pristis pectinata. Endang Species Res 12: 179-19

Submitted: September 12, 2017; Accepted: October 2, 2018 Proofs received from author(s): December 13, 2018 